821.163.41.09 Пекић Б.

$81: 32$

https://doi.org/10.18485/sj.2021.26.1.24

ЈАСМИНА М. АХМЕТАГИЪ ${ }^{*}$

Институт за српску културу Приштина - Лепосавић

Лепосавић
Оригинални научни рад

Примљен: 13. 10. 2020.

Прихваћен: 12. 1. 2021.

\title{
БОРИСЛАВ ПЕКИЋ: ЈЕЗИК ПОЛИТИКЕ, ПОЛИТИКА ЈЕЗИКА
}

Полазећи од кратког политичког есеја Борислава Пекића, у коме се подвргава критици манипулативна употреба језика, преобликовање стварности језиком политике, истражујемо на који је начин пишчево повезивање језика политике и политике језика (а потоња, представљајући инхерентне развојне могућности сваког појединачног језика, омогућава прву) одјекнуло у његовом делу. У нашем фокусу је језички манипулативни потенцијал као тема и садржај који је писац промишљао како у својим есејима тако и шире у свом књижевном опусу. У оба случаја Пекић осветљава језик као важно средство друштвеног деловања.

Језик политике, тврди Борислав Пекић, открива њену сврху, а ова се огољује кроз свесне и хотимичне, пре свега лексичке промене настале под утицајем друштвено-политичих и културних установа. Методолошке ослонце за ово дескриптивно-експликативно истраживање налазимо у социолингистичкој теорији и, делимично, анализи дискурса.

Кључне речи: Борислав Пекић, употреба језика, језик политике, манипулација, метафора.

„Језик је, колико је то могуће, објективна, искрена слика стварности или пут да се она на неискрен и пристрасан начин заобиђе и пренебрегне", писао је Борислав Пекић 1983. године у свом есеју „Предлог за употребу језика”, имајући у виду да је језик пре свега средство, медиј, алатка за исказивање 
стварности. О стварности се, како је ту јасно предочено, може говорити истинито, или се о њој може лагати, што имплицира да постоји веродостојан језички репертоар којим би се стварност (која језику претходи) могла аутентично представити. Судећи по овим речима, улога језика је референцијална, а Борислав Пекић - мада у свом кратком тексту говори о сасвим конкретној, друштвеној и политичкој стварности социјалистичке Југославије - конзервативан у својим погледима на језик јер су осамдесетих година конструктивистичке идеје, идеје о дискурзивном обликовању идентитета већ увелико присутне у култури и морале би се јавити и код писца који се сматра једним од представника српског постмодернизма.

И заиста, почињући са таквом тврдњом, Пекић надаље - и то постаје кључни садржај његовог кратког есеја - развија мисли о језику као моћном средству обликовања стварности.

Инсистирајући на исправном именовању, позивајући да се вратимо језику „у коме је поп поп, а боб боб” (Пекић 1983: 38), Пекић упућује захтев за металингвистичким промишљањем и вишим нивоом рефлексивности у погледу употребе језика, која је сведочанство о самој природи стварности. Сваки проблем који се тиче људске стварности - како следи из таквог става - у исти је мах и лингвистички проблем. „Језик јесте, и увек је био средство којим конструишемо и анализирамо оно што зовемо 'реалност"” (Лејкоф 2000: 20). Позивајући на исправно именовање стварности, Пекић пледира за прецизност, одређеност, јасноћу и диференцираност појмова и термина, дотичући тако вајкадашњи лингвистички проблем језичких промена. Лингвистика је одавно указала на промене у језику које се не развијају спонтано, већ су наметнуте, а осмишљене с намером и манипулативним циљевима. На границу спонтаних промена у језику и промена које су „наметнуте одозго” упозорио је и Лејкоф у својој књизи Talking Power: „Према променама које спонтано долазе у језику, одоздо, или из самог језика, наша политика треба да буде, 'Оставите језик на миру, и оставите његове говорнике на миру!' Али друге форме језичке манипулације имају друго порекло, друге мотиве, друге ефекте, и далеко су опасније" (цитирано према Камерон 1990: 4). Пекићев есеј, почев од наслова - „Предлог за употребу језика” - позива на отпор манипулативном именовању стварности и тако релативизује у лингвистици углавном проказану језичку прескриптивност.

Исто питање које је поставио Пекић 1983. појавило се у априлу ове године у часопису Време, у контексту актуелне пандемије, показујући своју универзалност: „Како именовање утиче на људе?” (Јоргачевић 2020). Метафора која стоји у основи књижевног изражавања и свеукупног стваралачки усмереног људског духа моћно је средство преобликовања стварности и манипулације. Лејкоф и Џонсон су утврдили да је наш концептуални систем 
фундаментално метафоричан и да игра централну улогу у дефинисању наших свакодневних реалности, мада то није нешто чега смо уобичајено свесни: „Метафора преовлађује у свакодневном животу, не само у језику већ у мишљењу и делању” (Лејкоф/Џонсон 2003: 4). „О вирусу”, како пише Ј. Јоргачевић (2020), „представници власти и дела стручне јавности говоре ратном терминологијом." Тако се поводом ковида-19 говори о биткама, савезницима, кривцима, противницима, победама, и то је појава која није типична само за Србију - тако говоре „и Орбан, и Трамп, и Макрон”, мада би било природније и далеко конструктивније да се одабере другачији језички реперотар који би умањио а не додатно подстицао страх и анксиозност код људи, како то чини ратна терминологија (в. Јоргачевић 2020). „Ратна метафора истиче одређене реалности и прикрива друге (...) Прихватање метафоре, која нас присиљава да се фокусирамо на оне аспекте нашег искуства који су истакнути, води томе да се и све оно што је собом обухватила прихвати као истинито (...)" (Лејкоф/Џонсон 2003: 7)

У две временски и по свом духу удаљене стварности - Пекићева социјалистичка Југославија и актуелна постмодерна друштва у којима влада пандемија (а постмодерна су јер подразумевају „постиндустријализам, конзумеризам и глобализацију" - Камерон 2005: 27) - појављује се истоветан однос према језику. Ако је ономад постојала „поштена интелигенција”, што имплицира да је та друштвена групација тек ексклузивно поштена и развија априорно неповерење према интелигенцији као таквој, данас постоји „нова нормалност”, што имплицира нужност прилагођавања и у исти мах пригушује потребу да се о таквој „нормалности” рефлектира, односно да се она доведе у питање. Пишући, сада већ далеке 1983. године, против језика социјалистичких фарисеја, Пекић је у исти мах приступио разобличавању једне политике језика која је универзални феномен, или прецизније: типичан модел тзв. постмодерног језичког менаимента (Камерон 2005: 27). „Есенција метафоре је разумевање и доживљај једне врсте ствари у терминима друге" (углавном мање конкретне реалности у терминима конкретнијег и више структурираног искуства), упозорава Лејкоф, скрећући нам пажњу да се метафора „расправа је рат” одражава у свакодневном језику на бројне начине, у низу широко распрострањених исказа, чега једва да смо свесни. „Метафора није само ствар језика, што значи, само речи (...) људски мисаони процеси су већином метафорични” (Лејкоф/Џонсон 2003: 7).

Пекић експлицира да је стварност пред језиком немоћна - „Јер језик је мења не додирујући је” - и то, како иронично додаје, „према себи и својим потребама" (Пекић 1983: 36), сугеришући да сам језик задобија статус субјекта. У том се исказу поистовећује језик са ауторитетом, у овом случају политичким, који га кодификује. Укратко, Пекић говори против промена у језику наметнутних „одозго”, тврдећи да језик једне политике открива њену сврху. 
Тако и промена имена једне политике, како објашњава, служи тек као маска за њен непромењен садржај. Пекић пледира за називање ствари њиховим правим именом, без еуфемизама (што значи и без политичке коректности) и упућује на нужност диференцирања неколико важних термина: национализма и родољубља, контрареволуције и демократског неслагања, неслагања и издаје. Колико је добро Пекић дијагностиковао проблем, сведочи чињеница да је замешатељство управо у употреби ових речи расло од осамдесетих година до данас продубљујући подељеност у српском друштву. Језик је, како је то лингвистика давно приметила, ,арена на којој одређени друштвени конфликти налазе свој симболички израз" (Камерон 2005: 11). Захтевајући да се служимо језиком који нешто значи, „а не сабласним језиком појмова којима у нашој емпирији више ништа не одговара" (1983: 39), Пекић побраја те речи-фантоме, односно флоскуле, чија је функција манипулативна, јер се иза њих не крије никакав стваран садржај (социјализам, самоуправљање, социјалистичка демократија, братство и јединство), а да је тако потврдила је сама стварност наредне деценије, односно распад социјалистичке, самоуправне, демократске Југославије на начин који обелодањује да ништа од тога није била.

Насловљен као „Предлог за употребу језика”, Пекићев есеј скреће пажњу на зависност језичке реалности од друштвеног поља моћи и имплицитно пледира за „вербалну хигијену, која се збива сваки пут када људи мисле о језику на критички (у смислу 'евалуативан') начин” (Камерон 2005: 9). Уосталом, у Златном руну, Пекић је своје Његоване - пре свега оне прворођене Симеоне који су челници фамилије у тренуцима када се ова налази на врхунцу свог материјалног благостања (Симеон Грк, Симеон Лупус и Симеон Газда) - приказао као субјекте моћи, значајне творце историје, којима је језик важно средство задобијања и практиковања те моћи, медијум кроз који се огледају „доминантне дискурзивне праксе и идеологије" (Де Фина 2006: 5). Језик неповерљивих Симеона изгубио је комуникативну функцију и постао средство за наметање значења, стога им и није познат истински дијалог. Управо узимањем у обзир свега што Његовани говоре или прећуткују, намеру и последице њихових говорних чинова, закључујемо да њихова друштвена интеракција корелира њиховој вољи за моћ. У постигнућима Симеона Грка ванредно значајну улогу има његова необична вештина у служењу говором, његов изванредан таленат за тзв. диване, за „соломонске разговоре”. Ту није реч ни о елоквенцији, ни о експресивности: специфичан дискурс овог јунака развио се из потребе да надмудри саговорника, што постиже нарочитом вербалном еквилибристиком, а управо га је вербална манипулативност уписала међу прваке његованског рода: циљ његових говорних чинова је подстицање саговорника да делају у смислу његових неексплицираних интереса, а не својих властитих. Симеон Грк, мајстор дивана, истовремено је и породична Питија: узмичући од сваке конкретности и прецизности, он стоји као антипод пишчевих захтева изра- 
жених у есеју: одређености, јасноће и диференцираности појмова и термина. Сви Симеони носе маску, па и језик којим се служе не изражава ништа од њиховог стварног садржаја и преокупација. Симеони репрезентују поступање са стварношћу које Пекић критикује у есеју „Предлог за употребу језика”: они језички преобликују стварност, симеонишу, диванииу, апотекарски зборе, на драм, док не произведу симулакрум, „нашминкани Шематизам” (Пекић 2005, II: 267). Велики број говорних ситуација у којима учествују Његовани потврђује да је реч о друштвеној ситуацији са неједнаком расподелом моћи: „индивидуално понашање рефлектује игру моћи, или је вођено (или можда чак и детерминисано) њоме” (Џозеф 2006: 2).

Као испуњавање једног од својих моралних задатака писац, а језичко преобликовање стварности иманентно је његовој вокацији, пише против језика политике која чини то исто са сасвим другачијим циљем и резултатима. Књижевноуметничко дело преобликује стварност како би истакло њену есенцију, док језик политике то чини како би је осиромашио и прекројио: уметност нас стога суочава са круцијалним питањима стварности, подстиче да их промислимо, а политика од њих одводи, успављује и анестезира. У Разарању гово$p a$, једној од драма ${ }^{1}$ у којој преиспитује судбину уметника у свету и бави се својом опсесивном темом односа уметника и грађанске стварности, Пекић то уверљиво показује кроз протагонисту Бориса, писца који се конформистички, посредством низа компромиса, сродио са тоталитарном стварношћу свога времена, те свој књижевни поступак прилагођава идеји којој служи, а која конвенира власти и стицању друштвеног успеха, односно његовом одржавању. Публикујући дела која су у толикој мери прочишћена од ризичног садржаја који би га могао довести у неудобну позицију контрареволуционарног писца, Пекићев јунак интернализује спољашњу цензуру, те свесним, конформистичким избором одржава и учвршћује поредак. Дистанцирајући се од непријатних животних истина, Борис посредством стварања разблажује свој однос са стварношћу, те постаје парадигма политичке коректности, а своје дело окамењује у стереотипима: „Смртоносност клишеа је у томе што су увек при руци и што заиста значе оно што изражавајуㄹ․ (...) Испод сваког клишеа стоји по један леш стварности" (Пекић 1984: 42)

Борислав Пекић, захтевајући у свом политичком есеју да користимо речи које имају значење и одговарају садржају стварности који именују, те да називамо ствари правим именима, упућује овде на опасност од готових решења, априорних уметничких образаца који су књижевном посленику увек при руци, као окоштале и уметнички мртве форме које подстичу и одржавају лењост духа.

${ }^{1}$ Написана је 1972, радио премијеру имала је 1973. у Келну, а у Београду је први пут изведена 1980. године.

${ }^{2}$ Подвукао аутор текста. 
Мада наизглед контрадикторни ставови, они се уливају у исти захтев који је уметности и књижевним ствараоцима упућивао Пекић - још у свом дневнику 1970. он пише да је став писца садржан у селекцији, „у ономе што је изабрао да види као и у ономе што је одбио да види" (Пекић 2013, II: 413). Дистанцирање од стварности, зарад конформистичке позиције награђиваног писца (што је случај са протагонистом Разарања говора), одржава се коришћењем готових решења: уместо живота, Његовани стављају нашминкани Шематизам, уместо проблема стварности, писац који је своје стварање прилагодио друштвеном успеху захвата стереотипне слике стварности, у којима уистину стварности и нема, које су и саме тек нашминкани Шематизам, симулакрум истоветан речима-флоксулама у језику политичара.

Уосталом, карактеризација јунака у Златном руну у знатној мери почива на употреби језика и начину комуникације: не треба заборавити да се млађа генерација Његована представља искључиво у дијалозима, будући да роман задобија драмску форму када представља садашњост, породични скуп у дому у Градишчини, на прослави Газдиног рођендана и Бадње вечери 1941. Уз особине које су кроз време пратиле овај генос, јављају се и оне које обележавају млађу генерацију, а сведоче о томе да се снага породице исцрпла. Посебан положај у том породичном ланцу припада Леониду Његовану, који по својој језичкој вештини подсећа на Симеона Грка, с тим што је она код њега изгубила сваку видљиву сврху. Уз то што се говором маскира, попут свих других Његована, овај јунак говором одржава дистанцу не само од свих непријатних, интимних разговора, него и од живота самог. Он говори прецизно и екстензивно, реторички бриљантно, уз то је аналитичан дух и завидног образовања, али је сам говорни чин у његовом случају замена за истински живот. Већ смо на другом месту писали о Леонидовој егзибиционистичој употреби језика (в. Ахметагић 2012), а овде нам је важно да укажемо на то да је управо Леонид творац речи без значења: „И кирикирија заслужује нешто да значи. Она заправо и значи нешто, само ми још нисмо открили шта. У почетку беше Реч, зар не? Откриће значења дошло је доцније и постепено" (Пекић 2005, I: 122). Леонид живи пре свега у лингвистичкој а не друштвеној стварности, свестан је манипулативног језичког потенцијала и тиме се обилато служи. Његову употребу језика Пекић види као репрезентативну за савременост. Циљ дијалога, како експлицира у есеју „Позив на дијалог”, јесте идентитетско потврђивање његових учесника: у сталном неслагању, псеудополемичности, одржава се илузија независног мишљења. Дијалог је тек размена речи која „неће нашкодити нашем мишљењу” (Пекић 1983: 10).

Поступно развијајући у „Предлогу за употребу језика” мисао да језик има потенцијал да постане стварност сама (односно да језик јесте стварност), Пекић ту идеју уткива и у своје дело, у роман Како упокојити вампира, што ћемо илустровати поглављем „Како је Адам Трпковић легао у кревет госпођи- 
це Лили Шварцкопф или Похвала лудости". Централни јунак овог романа, Конрад Рутковски, летујући у месту Д. у коме је боравио и две деценије раније као СС-официр, у низу писама које упућује свом шураку, приповеда о властитом ратном искуству и како је настојао да спасе затеченог ухапшеника, општинског деловођу Адама Трпковића од злоћудне и омнипотентне истражне стратегије свог претпостављеног, пуковника Штајнбрехера, развијајући дијалог са европском филозофијом, те и премештајући кривицу са себе у намери да растерети савест у чијим дубинама лежи сазнање да је одговоран за једну смрт. Супериорни Штајнбрехер, у односу на којег Рутковског мучи и осећање инфериорности (а претпостављени их и директно и немилосрдно изазива) представљен је као парадигма иследника који влада режираним процесима - a ови су били велика, интимна и болна Пекићева тема, с обзиром на властиту затворску прошлост, дубоко неслагање са системом у коме је живео, те бројне непријатности које је и након пуштања на слободу искусио. Аутобиографско-мемоарска проза Године које су појели скакавии доноси бројне примере штајнбрехеровске логике са којима се писац суочио у истражном систему једне комунистичке земље. У Како упокојити вампира та је логика - а пре свега језичка производња стварности - језгровито и упечатљиво приказана у поменутом поглављу у коме се доводе у везу неупадљиви општински деловођа из места Д. у Југославији и модисткиња, шпијунка Лили Шварцкопф из Манхајма, која и сама, у часу када се истрага обавља, нема исти онтолошки статус као други јунаци, већ функционише као метафора, лик преузет из туђе истраге: другим речима, постоји као фикционална јунакиња, у металитерарној равни. Штајнбрехерова истражна поетика - „Вредност питања са гледишта истраге (...) не цени се мером у којој оно обухвата реалност, већ степеном у коме, одбијајући је, испитаник прихвата неку другу, такође измишљену али безопаснију" (Пекић 1991: 152) - владала је режираним стаљинистичким процесима (подлеже јој и Кишов Борис Давидович), а Пекић је готово теоријски промишља, доводећи њено есенцијално оружје (које је именовао као полицијски гамбит) до апсурдног степена, како би у целини, рационалним путем оголио њен механизам. Стога Рутковски у својој истрази поставља Адаму Трпковићу једно апсурдно питање, подражавајући дух и логику Штајнбрехерових упитника, који представљају ,језичку политику у акцији” (Лејкоф 2000: 24): „Реците нам када сте први пут спавали са госпођицом Лили Шварцкопф из Манхајма” (Пекић 1991: 151). „Чудовишно по идеји, оно је савршено репродуковало бројне и непознате стварности у које ће деловођа бити гуран" (Пекић 1991: 152). Будући да од деловође (којег жели да спасе) добија тачан датум, Рутковски прекида истрагу, али имагинира њен даљи ток, те читалац присуствује прецизном и детаљном обликовању стварности - фикције - која оптуженог води на губилиште. Историја је препуна егзекуција због лажних оптужби, али Пекића овде занима страдање које је последица тоталитарног мишљења које се огледа у језику: сам језик преузима овде улогу чина. 
Илуструјући, преко случаја Адама Трпковића, своје искуством стечено уверење - да малих признања, а ни малих компромиса, нема - Пекић приказује настанак фикције у току истраге, која је пар екселанс говорни чин, а која, попут сваке фикције подлеже аристотеловским начелима вероватноће и уверљивости. Адам Трпковић, репрезентант политичког затвореника, принуђен је да непрекидно одабира између понуђених опција, између два мања зла, од којих оба припадају лингвистичкој стварности. Потенцијални догађај се преображава у реалан, какве постају и кривица и казна. Штајнбрехер, уосталом, размишља о „правим лингвистичким трагедијама” које се збивају на саслушањима, позивајући Рутковског да дубље размисли о језику: „Готово по правилу, под извесним појмовима подразумевамо нешто друго него затвореник. Језик којим са њима саобраћамо је исти, али као да се у спољњем изгледу исцрпљује свака сродност. Значења им потичу из два различита извора. (...) Онај ко тврди да је за нешто невин, не каже тиме да није крив за нешто друго. Одбијање оптужбе за саботажу на аутомобилу не искључује аутоматски и будуће признање за саботажу на возу (...) Идеалан језик саслушања морао би бити апсолутно једнозначан, универзалан и логички доследан. Истина би произилазила из реченица, а не из њиховог смисла" (Пекић 1991: 190). Штајнбрехер манипулише променом контекста (његовим хотимичним проширивањем и сужавањем) који мења значење сваког исказа, а илуструје и, како Рутковски запажа, „Карнапову семантичку тежњу”: „Оно у чему се споримо увек је смисао исказа. Ако би он увек произилазио само из свог облика, неспоразума би нестало, јер би се сви могући облици унапред могли утврдити (...) Имали бисмо посла само са затворениковим реченицама, док се сада мучимо не само са њиховим смислом, већ и са свим психолошким, менталним па и физичким изворима који је условљавају" (Пекић 1991: 190-191). Штајнбрехерова чежња за једнозначношћу, која би одвојила човеков језик од свега што човек уистину јесте, и значила механички израз, свођење хумане на роботску, компјутерску суштину, апсолутну логику, одговара његовој националсоцијалистичкој идеологији, којој је фанатично одан колико и свом истражном послу („чему очи”, пита се Штајнбрехер, „ако ништа не одају?” - Пекић 1991: 47). Апсолутна логика и апсолутна рационалност, примењена на људско биће, значила би апсолутну победу зла.

Као и у случају свих других филозофа са којима се у својим писмима спори, Рутковски и Карнапову логичку синтаксу искривљује и представља на неистинит начин, чинећи Штајнбрехера његовим присталицом - и тиме сугеришући да је претходница његовог нечовечног погледа на свет присутна у филозофији, односно исписујући имплицитну апологију и пуковника Штајнбрехера и посредно, самога себе. У томе је, уосталом, и смисао јунаковог исказа да „РЕЧ ПОПРАВЉА ДЕЛО” (Пекић 1991: 23) Логичка синтакса Рудолфа Карнапа омогућава формалну теорију језика, а ова обухвата његову 
граматичку, а не семантичку страну, те јој је и циљ сасвим другачији од оног који сугерише Рутковски, смештајући и апстракни језик Витгенштајновог логичко-филозофског трактата у баналне оквире полицијске истраге. Рутковски тврди да је Штајнбрехеров сан сличан сну највећих логичара, чије идеје манипулативно искрвиљује како би то доказао, а заправо чини оно што му је психолошки погодније - објашњавање стоји на месту исповести, чиме уздиже своју личност из злочинца у теоретичара интелектуалца.

Адам Трпковић, притиснут да начини ма какво признање, најпре пристаје на политичко тумачење свог непоздрављања италијанске заставе, мада је разлог тог чина лежао у баналној чињеници: тог ветровитог дана руке су му биле заузете придржавањем огромног кишобрана. У том часу затвореник рачуна на актуелно погоршање односа између влада двеју држава а не на полицијску логику, којој прво признање отвара простор за осмишљавање стварности у коју ће насилно и без додира са истином, угурати општинског деловођу. Јер, циљ истраге у тоталитарним системима, како тврди Пекић, није истина, него признање. Одговори ислеђиваног су „тек обликовање иследникових сугестија”, а признање ,апсолутно преузимање туђе (измишљене, вештачке) стварности за своју” (Пекић 1991: 158, 159). Пекић овде указује на улогу оквира („концепт оквира као начин посматрања међусобног утицаја језика и искуства развијали су когнитивни теоретичари од седамдсетих година прошлог века" - Лејкоф 2000: 47) који структурира очекивања учесника у дијалогу. „Оквири су есенцијални део нашег когнитивног репертоара. Они нам омогућавају да правимо предикције и генерализације” (Лејкоф 2000: 48). И Штајнбрехер, и Симеон Грк, свој успех дугују, између осталог, неочекиваној промени оквира и наметању саговорнику нових услова у којима се не могу осећати комфорно: напротив, „преформулисање оквира је трауматично” (Лејкоф 2000: 48).

Упозоравајући на политичку манипулацију посредством језика и приказујући зависност језика ликова од друштвене расподеле моћи, Пекић, на фукоовском трагу, показује да је језик и политички феномен. Интерпретирање језика на начин на који то писац чини у свом есеју, али и у предоченим романескним примерима, представља политички чин. Откривајући како субјекти моћи користе језик за постизање циља и политичко значење говора својих јунака (дивани Симеона Грка, политичка самоидентификација писца Бориса преко језика политичке коректности и стереотипних слика којима не дира у поље које би на било који начин угрозило владајућу елиту), Пекић истиче политичку димензију језика. Штавише, роман Како упокојити вампира сам је по себи пример далекосежних последица манипулативног односа према језику: полемика са западноевропском интелектуалном традицијом коју води Конрад Рутковски заправо је рационализација, одбрамбена стратегија којом штити своју личност од распада, који тако и пролонгира, те са тим циљем фалсификује традицију с којом полемише - аутор градећи такво значење ро- 
мана, предузима „семантичку деформацију и очуђење” (Ораић Толић 1990: 39) коришћених предложака. Уз све оно што Рутковски заиста чини (пише писма, настоји да исправи историјску неправду те укаже на чињеницу да се споменик подиже погрешном човеку, креће у рат против кишобрана), стоји и други слој који чини једнако важан садржај романа, а састоји се од међусобног сучељавања низа говорних чинова. Важна тема романа јесте манипулација језиком, изговореном речју, те производња симулакрума од којих се, како је то Пекић показао, састоји највећи део полицијске истраге. Поднаслов романа - „сотија” - и указује на ту полемичност са туђом речју. „Језик постаје место борбе за самодефинисање" (Лејкоф 2000: 86).

Уосталом, у делу Борислава Пекића присутан је читав развојни спектар односа према језику: реализам какав се јавља у цитату с почетка текста (уверење да је језик референцијалан, да је тек одећа за мисли која не утиче на њихов садржај, средство за декодирање реалности), али и концептуализам, који подразумева да је ,језик фундаменталан и поседује обликотворни утицај на мисли" (Џозеф 2006: 115). Стога се на питање шта је заједничко Леониду Његовану, пуковнику Штајнбрехеру и југословенској социјалистичкој елити осамдесетих може одговорити - концептуалистички приступ језику, који је код њих несвестан и имплицитан, али и те како делатан. Сви они посредством језика производе стварност која по својим последицама није нимало мање очигледна од онога што се уобичајено, у општем смислу сматра друштвеном стварношћу.

\section{ЛИТЕРАТУРА}

Ахметагић 2012: J. Ahmetagić, Priča o Narcisu zlostavljaču, Beograd: Službeni glasnik.

Де Фина и др. 2006: A. De Fina, D. Schiffrin, M. Bamberg (Eds), Discourse and Identity, New York: Cambridge University press.

Јоргачевић 2020: J. Jorgačević, Kako čitati javni govor: (Zlo)upotreba jezika u doba korone, Vreme, 1527, 9. 4. 2020. https://www.vreme.cgom/cms/ view.php?id=1771884\& (преузето 11. новембра 2020).

Камерон 2005: D . Cameron, Verbal Hygiene: The Politics of Language, London, New York: Routledge.

Лејкоф 2000: R. T. Lakoff, The Language War, Berkley, Los Angeles, London: University of California Press.

Лејкоф/Џонсон 2003: G. Lakoff, M. Johnsen, Metaphors we live by, London: The University of Chicago press. 
Ораић Толић 1990: D. Oraić Tolić, Teorija citatnosti, Zagreb: Grafički zavod Hrvatske.

Пекић 1983: B. Pekić, Predlog za upotrebu jezika, Odmor od istorije, Beograd: BIGZ.

Пекић 1984: B. Pekić, Tamo gde loze plaču, Beograd: Partizanska knjiga.

Пекић 1991: B. Pekić, Kako upokojiti vampira, Beorad: Prosveta.

Пекић 2005: B. Pekić, Zlatno runo, I-VIII, Beograd: Dereta.

Пекић 2013: B. Pekić, Život na ledu, I-V, Beograd: Službeni glasnik.

Џозеф 2006: J. E. Joseph, Language and Politics, Edinburg: Edinburg University Press.

\section{BORISLAV PEKIĆ: LANGUAGE OF POLITICS, POLITICS OF LANGUAGE}

\section{Summary}

Starting from a short political essay, in which Borislav Pekić criticized the manipulative use of language and reshaping of reality through the language of politics, we explore how the writer's connection between the language of politics and politics of language - and the latter, representing the inherent developmental possibilities of each individual language, allows the former - resonates in his works. Our focus is on linguistic manipulative potential as a topic and content that the author had considered both in his essays, and more widely in his literary oeuvre. In both cases Pekic suggests that language is an important means of social action.

The language of politics, claims Borislav Pekić. reveals the purpose of the politics, and this is exposed through concious and deliberate, primarily lexical changes that have occurred under the inluence of socio-politacal and cultural institutions. Methodological supports for this descriptive-explicative research we found in sociolinguistic theory and, in part, discourse analysis.

Keywords: Borislav Pekić, usage of language, language of politic, manipulation, metaphor. 